\title{
The Urgency of Bajo Traditional Law as a Form of Law Enforcement Against the Performers of the Samenleven Delic
}

\author{
Lusiana Margareth Tijow \\ Universitas Negeri Gorontalo, Gorontalo, Indonesia, Jl. Jend. Sudirman No.6, \\ Dulalowo Tim., Kota Tengah, Kota Gorontalo, Gorontalo 96128 \\ E-mail: lusianamtijow@gmail.com \\ Hoiruddin Hasibuan \\ Universitas Wisnuwardhana, Malang, Indonesia, Jl. Terusan Danau Sentani \\ No.99, Madyopuro, Kec. Kedungkandang, Kota Malang, Jawa Timur 65139 \\ E-mail: hasibuan36@gmail.com
}

\begin{abstract}
Hayat
Universitas Islam Malang, West Java, Indonesia, Jalan Mavien Haryono No.193, Dinoyo, Kec. Lowokwaru, Kota Malang, Jawa Timur 65144

E-mail: hayat@unisma.ac.id
\end{abstract}

\begin{abstract}
Life in Indonesia does not recognize Samenleven's relationship because the rules of law and religion do not justify it, but there are still many things like that in Bajo Village. Bajo customary law includes the Bajo Customary Institution. In this institution, its existence helps the village government develop and regulate matters relating to local customs and solving problems regarding adultery, namely Samen Leven. This paper describes how customary law can be used as a law enforcement instrument to resolve the Samenleven offense. Semenleven is living together between a man and a woman without a legal marriage bond. This research uses the type of empirical normative research. The data types used are primary and secondary data sources using several approaches. The results show that the use of Bajo customary law, as a form of law enforcement against the perpetrators of the Samen Leven offense, will create a bargaining justice where customary law is used as the first route in resolving a conflict between victims, perpetrators, and the community. The consequence is that the perpetrator must admit that he has been guilty and is willing to take responsibility for his mistake following applicable customs. The Bajo Customary Council uses customary law as a reference to resolve any problems that occur in Bajo Village, Tilamuta District, namely customary law by deliberation/mediation.
\end{abstract}

Keywords: customary law; law enforcement; Samenleven. 


\section{INTRODUCTION}

Customary law is the community's traditional law, which embodies a real need for life and is a way of looking at life, which is the culture of the community where the customary law applies. Customary law is also the value that lives and develops in the community of a region. There are separate sanctions from the community if they violate the rules of customary law.

Customary law that lives in a society still thick with its original culture will be felt (Firhan, 2019). The application of customary law in everyday life is also often applied by the community. Even if a judge faces a case and cannot find it in written law, he must find the law in the rules that live in society, meaning that the judge must also understand customary law. Customary law can be said to be the civil law of the Indonesian people.

Customary law can be a form of legal culture used by the community for generations to regulate life guidelines in a customary law community (Hanim \& Noorman, 2018). Customary law communities' lives are bound by solidarity with equal interests and awareness. As a legal culture, customary law is a formulation of rules whose formation does not go through rules that are not legislative but are born from popular opinions and reinforced by customary sanctions (Pide, 2017; Zazili, 2016).

Today's developments and rapid developments have made many individuals take the same action or hang out together. Kumpul Kebo is a pretty popular term in the community to refer to the act of living together outside of a legal marriage. Living together (Samenleven) is a natural phenomenon in people's lives. The act of living together between men and women without being bound by a legal marriage is a common thing to do in society. The assumption among these circles is that it is part of modern life. Kumpul Kebo (Samenleven) is seen by most Indonesian people as a disgraceful act and includes a crime against decency (Dermawan, 2015; Hikmah, 2013). However, in today's Criminal Code, coming from Wetboek Van Strafrechtvoor of the Dutch East Indies (WvS), gathering together is not stated as a punishable act.

Kumpul Kebo (Samenleven) is often interpreted as living in one house but not bound or not through a legal marriage process. The issue of adultery has been regulated in the Criminal Code (KUHP), wherein Criminal Code several articles regulate adultery. The categories or criteria included adultery described in the Criminal Code are those committed by those who commit it. Zina is a legal marital status and then commits the act with his marital partner. So it can be concluded that the article referred to in the Criminal Code only applies to those already married.

Samenleven, by most of the majority of customary law, still living and developing in Indonesia, is considered a crime of morality. Therefore the legislators include customary law (gewoonrecht) into the Draft Criminal Code contained in Article 485, which states that "everyone who lives together as husband and wife

The Urgency of Bajo Traditional Law as a Form of Law Enforcement Against the Performers of the Samenleven Delic Lusiana Margareth Tijow, Hoiruddin Hasibuan, Hayat 
outside a legal marriage, shall be punished with a maximum imprisonment of 1 (one) year or a category II fine".

About the inclusion of cohabiting in the Draft Criminal Code, there appear to be several pro and contra opinions that will lead to horizontal conflicts. The purpose of the offense in the Draft Criminal Code is to regulate cohabiting according to positive law in force in Indonesia.

Efforts to overcome crime can be taken by: 1) Application of criminal law (criminal law application); 2) Prevention without punishment (prevention without punishment); 3) Influencing the views of society on crime and punishment through mass media (influencing views of society on crime and punishment) (Moeljatno, 2015).

G.P Hoefnagels' crime prevention can be broadly grouped into two parts, namely penal crime prevention and non-penal crime prevention. The penal policy is a form of crime prevention that focuses on repressive actions after a crime, while non-penal policy emphasizes preventive actions before a crime (Hoefnagels, 1969).

According to the political view, the criminal non-penal policy is the most strategic crime prevention policy. It is preventive before the occurrence of a crime. Non-penal means dealing with and eliminating conducive factors that cause a crime; considering that crime prevention efforts through non-penal channels are more of a preventive measure for crime, the main target is to deal with the conducive factors that cause crime (Iskandar, n.d.; Pide, 2017).

Adat is an unwritten norm but is solid binding so that community members who violate customs will suffer due to harsh sanctions that are sometimes indirectly imposed. For example, in a society that forbids divorce, a person concerned gets sanctions or becomes polluted, but the whole family or community. Customs are rules, habits that grow and are formed from a community or area valued, upheld, and obeyed by the supporting community. In Indonesia, the rules regarding human life become binding legal rules called customary law. Customs have been institutionalized in people's lives in the form of traditions, ceremonial customs, and others that can control the behavior of community members with feelings of pleasure or pride, and the role of traditional leaders who become community leaders is quite essential. One of the laws that apply in the Unitary State of the Republic of Indonesia, whose existence is highly recognized by the public, is Customary Law.

What is meant by customary law is the oldest and unwritten law, but its existence is highly recognized and upheld by all communities in the area or village. Usually, the customary law will be a reference for certain parties such as customary stakeholders and the government in resolving a problem or case in the region or village before the case or case will be resolved by national law or positive law (law).

Customary law develops following the development of society and existing folk traditions. Customary law is a deposit of decency in a society whose truth gets

The Urgency of Bajo Traditional Law as a Form of Law Enforcement Against the Performers of the Samenleven Delic Lusiana Margareth Tijow, Hoiruddin Hasibuan, Hayat 
recognition in that society. In its development, the practice that occurs in customary law communities the existence of customary law often raises questions whether these customary law rules can still be used to regulate people's daily activities and solve problems that arise in customary law communities. Meanwhile, our country also has legal rules made by law-making bodies or institutions and other laws and regulations. Customary and state laws have different binding powers, which are constitutionally the same, but there are differences in their forms and aspects.

According to Van Vollenhoven in Wulansari and Gunarsa (2016), customary law is the general rules of community behavior that apply and have sanctions and have not been codified. According to Terhaar in Hamzah (2014), customary law is the entirety of regulations embodied in day-to-day decisions and applied spontaneously. It can be concluded that customary law is an unwritten norm or regulation made to regulate people's behavior and has sanctioned. Recognition and protection of the rights of indigenous and tribal peoples are critical by the state. Customary law communities were born and existed long before Indonesia was formed. In its development, customary law communities have adapted to the principles and spirit of the Unitary State of the Republic of Indonesia. Through the normative requirements in the legislation itself, indigenous peoples are merged into state citizenship.

The Bajo Customary Council is a community of indigenous peoples who firmly uphold family values, created the Bajo community's local wisdom. Customary law recognizes customary sanctions that apply to anyone who commits a crime or violates rules and norms contrary to the public interest. Crime is seen as an act that deviates and is against the public interest. One of the problems or public problems that many people think must have legal force is Kumpul Kebo (Samenleven), or what is often interpreted as living in one house but not being bound or not going through a legal marriage process. Even though the issue of adultery has been regulated in the Criminal Code (KUHP), in the Criminal Code, some articles regulate adultery. Still, the categories or criteria included in the adultery described or referred to in the Criminal Code are those who have legal marital status then perform the act with their marital partner. It can be concluded that the article referred to in the Criminal Code only applies to those who already have a wife or husband.

The balance of life in society can occur if the laws that govern it can be implemented, respected, and not violated. So that if some of the norms (both written and unwritten) are violated by a small number of community members, it will undoubtedly cause turmoil in society. For example, Samenleven, which is the act of living together between a man and a woman without a legal marriage bond, has become a common thing in society, assuming that it is a part of modern life. Various reasons were expressed by those who claimed to have cohabited, for example, because of limited funds, not getting the blessing of both parents, or to fulfill inner pleasures. 
Gathering together in Dutch is called "Samen Leven" in the draft law on the Criminal Code. Gathering together is a criminal act that is punishable by a criminal penalty. Kumpul Kebo is included in a decency offense previously unknown in the colonial-made Wetboek van Strafrecht (WvS), codified into the Criminal Code.

Kumpul Kebo is better known as "Samenleven" or "living in nonmatrimonial," "conjugal," "cohabitation" is a popular term in society to refer to the act of living together. Outside a legal marriage" (Efendi, 2018). Gathering together is seen by most Indonesian people as a disgraceful act and includes a crime against decency.

Religion and applicable law do not justify this act. Consciously or not, humans are influenced by the rules of life that apply to curb lust and regulate relationships between humans. These life rules show which actions can be carried out and which should be avoided.

In Islam, adultery includes uncivilized sexuality because it comes out of the concept agreed upon by Islam. Before Islam came, adultery was an act that was not prohibited. As stated above, legitimate sexuality is sexuality that is approved by Islamic law. Thus, adultery is another form of sexual perversion. Therefore, the person who commits adultery will be given the criminal penalty of Jinayah. As in the letter QS. Al-Isra ': 17:32 and QS. An-Nur/24:02. In Islam, Samenleven is considered an act that can damage morals and damage a marital relationship between a husband and wife.

Adultery and cohabitation are one form of huddud jarimah, where the punishment has been determined by the shape and size according to the syar'i. Proper punishment for adulterers (gathering together) is lashing 100 times as agreed by the fuqoha' and also required for adulterers (gathering together) to be punished with taghrib or exile for one year.

One of the customary sanctions in the Traditional Village, which is still valid today and is recognized by the Bajo adat community, is the Bajo adat sanction. Bajo is one of the areas that since the beginning of the formation of the Bajo village, it is still consistent with custom and still recognizes its customary law even though only a few customs are still left in Bajo Village today. One of the things still regulated by Bajo customary law is Samenleven, namely, people who live in the same house but have not gone through a legal marriage process. Bajo is an area based on history; they are archipelagic people because they live on islands and then form their area inhabited by the Bajo tribe, which is then called the Bajo area. Meanwhile, another history is that the language used by the Bajo people has a common language with several regions such as Bugis, Javanese, and the Philippines. The Bajo village has almost the same characteristics as the Bugis, Javanese, and Filipino.

Many immoral problems often occur in everyday life. One of them is the immoral problem in the Bajo village, namely the problem (Samenleven) or what is

The Urgency of Bajo Traditional Law as a Form of Law Enforcement Against the Performers of the Samenleven Delic Lusiana Margareth Tijow, Hoiruddin Hasibuan, Hayat 
called living in one house without going through a legal marriage process. Any problems (Samenleven) or adultery in Bajo Village carried out by men and women, both married. Teenagers will be resolved by deliberation by the village government and the customary council. Usually, the village government allows the adat council to resolve the issue. Suppose both parties are proven to have committed adultery. In that case, the village government and the customary council will marry off the two parties even though one of the parties objected to the decision. This explanation is, of course, contrary to one of the principles of marriage, namely the principle of agreement of both parties, which means that there is no compulsion in marriage. Still, until now, there has been no coercion in carrying out marriages carried out by the village government or the customary council itself against the parties. Litigants because the parties to the litigation still agree with all decisions of the village government and the customary council based on deliberation and consensus. However, suppose the problem cannot be resolved amicably by the village government and the customary council together with the litigants. In that case, the village government and the adat council will hand over the case to the authorities for legal processing or resolution. However, there have been no parties who object to the decision of the adat council or the Bajo village government.

\section{RESEARCH METHODS}

This research is a type of normative-empirical legal research using several approaches. The philosophical approach, the statute approach, and the case approach are among them. The data types used are primary data sources obtained from interviews with resource persons and secondary data sources obtained from various related sources or references, both from journals and books.

\section{RESULTS AND DISCUSSION}

\section{The urgency of Bajo Customary Law as a form of law enforcement against the perpetrators of the Samenleven offense}

Indonesia is a country that adheres to plurality in its legal field, where there are three laws whose existence is recognized and enforced, namely western law, religious law, and customary law. In practice, there are still many people who use customary law to regulate their daily activities and solve an existing problem. Each region in Indonesia has its customary law system to regulate diverse social life, most of which are not written rules (Pide, 2017).

The customary law develops following the development of society and existing folk traditions. Customary law is a deposit of decency in a society whose truth gets recognition in that society. In its development, the practice that occurs in customary law communities the existence of customary law often raises questions whether these customary law rules can still be used to regulate people's daily activities and solve problems that arise in customary law communities. Meanwhile, our country also has legal rules made by law-making bodies or institutions and other laws and regulations. Customary and state laws have different binding powers,

The Urgency of Bajo Traditional Law as a Form of Law Enforcement Against the Performers of the Samenleven Delic Lusiana Margareth Tijow, Hoiruddin Hasibuan, Hayat 
which are constitutionally the same, but there are differences in their forms and aspects.

According to Van Vollenhoven in Wulansari and Gunarsa (2016), customary law is the general rules of community behavior that apply and have sanctions and have not been codified. According to Terhaar, customary law is a set of regulations embodied in day-to-day decisions and applied spontaneously. It can be concluded that customary law is an unwritten norm or rule that regulates people's behavior and has sanctions.

The state has officially recognized this customary law, but its use is limited. Referring to Article 18B paragraph (2) of the 1945 Constitution, which states, "The state recognizes and respects the unity of indigenous peoples and their traditional rights as long as they follow the development of society and the principles of the Unitary State of the Republic of Indonesia." The Unitary State of the Republic of Indonesia as regulated by law." this means that the state recognizes the existence of customary law and its constitutional rights in the Indonesian legal system.

Customary law in Indonesia has the same pattern in resolving community conflicts. Each indigenous community has a customary institution in charge of controlling individual behavior in the community and carrying out penalties if there is a violation of customary law. The application of customary law also reflects the protection of victims' rights, which have been regulated by customary law. However, on the one hand, the suspect's rights are also not ignored; this is the justification of the due process model in which state power is limited to guarantee individual rights legally.

There is customary law and written law in the Bajo area, but in every problem solving, adultery, theft, and other problems, customary law is used. The Bajo area is an area that still enforces and recognizes its customary law; of course, it has its customary sanctions for perpetrators of adultery (Samenleven) or other customary violations.

In Bajo customary law, a customary institution was formed in 2017 and had a customary board chaired by Mr. Ustad Kasmun and has eight members, two ladies-in-waiting, and six men. These traditional administrators play an active role in solving every problem and carrying out a traditional activity in the Bajo Village.

This Bajo traditional institution functions when there is a problem in the Bajo village, whether it is a matter of adultery (Samenleven), theft, alcohol, or other problems will be resolved by deliberation by the customary institution and the village government together with the parties concerned. If the parties are proven to have committed adultery (Samenleven), then they will be married even though one of the parties or the litigating parties object to the decision.

In this Bajo custom, if a fellow teenager commits an immoral or Samenleven violation, the settlement process will be completed according to custom by the

The Urgency of Bajo Traditional Law as a Form of Law Enforcement Against the Performers of the Samenleven Delic Lusiana Margareth Tijow, Hoiruddin Hasibuan, Hayat 
customary holders and the village government. The settlement process will only be resolved by deliberation, "if the person committing adultery or Samenleven is a fellow teenager, the settlement process will be completed according to custom. But if the teenager carries out the act together with people who already have a husband and wife relationship, it will be resolved by deliberation and consensus. Adat will not interfere," said Mr. Kasmun.

The Bajo customary sanctions imposed on adulterers (Samenleven) as well as for people who commit other customary violations are as follows: Results of an Interview with the Chairman of the Customary Council, December 24, 2019, On Tuesday at 19.30 in Bajo Village:

\section{Married (for Samenleven actors)}

The act of immoral violation, namely adultery (Samenleven), was committed by the local village community. People outside the Bajo village also carried out the act. However, the settlement process is the same as the Bajo community who carried out the act. The parties, including their families, will be invited to deliberation with the Bajo village government and the customary council. If people commit the act, it will be reported to the village head as the retainer. After that, the village head will invite the parties concerned and contact the families of both parties to carry out deliberation at the village office with the village head and the customary council. If it is proven guilty of having committed the act, then the two parties will be married even though one of the parties or both of them is not old enough and has objections.

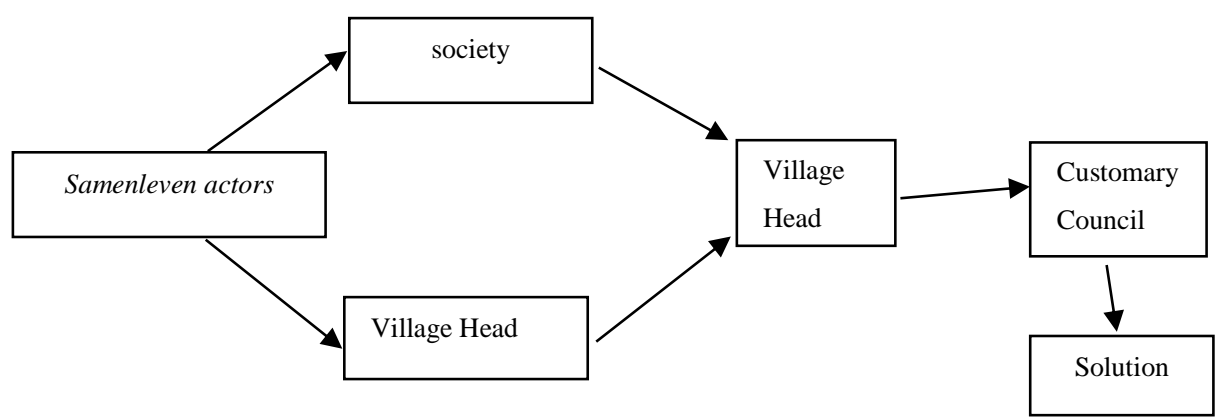

Figure 1. Process for reporting the Samenleven perpetrators in the Bajo indigenous community.

From the chart above, it can be explained that the perpetrators of Samenleven are people who have committed immoral violations in Bajo village because Samenleven is a form of immoral violation or adultery for that law enforcement is needed for these actions. Reports from the community then go to the head of the hamlet as the person who leads the village.

However, because Samenleven is a matter that is carried out securely and cannot be monitored directly by the head of the hamlet, the community who can witness the act also have the right or can be involved in reporting the problem to

The Urgency of Bajo Traditional Law as a Form of Law Enforcement Against the Performers of the Samenleven Delic Lusiana Margareth Tijow, Hoiruddin Hasibuan, Hayat 
the village head. When this problem has been reported, the village head (punggawa) will immediately act and deal with the problem and involve the customary council as an institution. That helps the village government handle and resolve the case so that the final process occurs in the settlement section, where all forms of action and deliberation of the parties will be decided in the settlement section.

\section{Will pay the fine according to the agreed terms}

The Bajo Traditional Village still upholds customary law, which imposes customary sanctions in the form of fines. However, this customary sanction is not applied to perpetrators of adultery or Samenleven but other perpetrators of customary violations. If the parties are proven to have violated the customs, they are required to pay a fine, but the customary fine is only given to the party who feels aggrieved. It is not much different from the legal provisions in force in Indonesia. However, the application of customary sanctions in the form of fines in this Bajo village sometimes some people do not pay the fine because there is no coercion on people who do not want to pay the fine.

\section{Men will be removed to the west and women removed to the east}

The Bajo area is an area that still uses customary law by applying customary sanctions to perpetrators of immoral acts such as adultery or Samenleven. If men and women commit immoral acts (Samenleven), the men will be removed to the west while the women will be removed to the east. The purpose of applying this customary sanction is so that the two parties no longer meet or cannot communicate either by telephone or through other social media. This customary sanction has been in effect since the formation of the Customary Institution in Bajo village in 2017, chaired by Mr. Kasmun.

\section{Stone stone}

The customary sanction by stoning with stones has never been carried out in Bajo Village because all problems that occur can still be resolved by deliberation or kinship and are accepted by the parties concerned.

In addition to providing customary sanctions, Bajo traditional institutions also play an active role in guarding marriages for Samenleven actors. The following are the results of an interview with Ustad Kasmun (Chairman of the Customary Council) on November 28, on Thursday at 18.30 in Bajo Village, including the following:

1. Bajo traditional institutions play a role in transferring assets or escorting proposals for Samenleven actors with the perpetrators' families. After the proposal is complete, the customary council will hand it back to the family.

2. One week later, the two parties to be married (the perpetrator of Samenleven) will be brought to the Office of Religious Affairs (KUA) for 
Jurnal Ilmiah Al-Syir'ah Vol. 19, No. 2 (2021): 256-266

Website: http://journal.iain-manado.ac.id/index.php/JIS ISSN 2528-0368 (online) ISSN 1693-4202 (print)

marriage. The marriage is only carried out at the Office of Religious Affairs because the marriage will not be held in a crowd.

3. After carrying out the marriage contract, the traditional institution will bring the bride and groom back to the family's house.

4. Customary institutions will also carry out safety prayers for both parties in one of the families' homes.

From the explanation above regarding the urgency of Bajo customary law, as a form of law enforcement against the perpetrators of the Samenleven offense, bargaining justice will be created where customary law is used as the first route in resolving a conflict involving victims, perpetrators, and the community. The consequence is that the perpetrator must admit that he has been guilty and is willing to take responsibility for his mistake following applicable customs. If the customary law is successfully implemented, then another advantage that the perpetrators will obtain is avoiding the publication of cases that may harm themselves and their families. Another advantage is the escort of the proposal to the marriage contract carried out at the Office of Religious Affairs for the Samenleven perpetrators who are married.

\section{CONCLUSION}

Customary law is a deposit of decency in a society whose truth gets recognition in that society. Customary law can be used as a law enforcement instrument to resolve the Samenleven offense. Kumpul Kebo is related to coexistence between a male and female partner without being based on a legal marriage bond. Customary violations or customary offenses and customary law settlement mechanisms have their way of resolving them. When there is a violation of adat, it is related to the imbalance of the cosmos in society. This includes actions that disturb the peace of life or violate decency in the society. Justice is defined as the process of finding solutions to problems that occur in a criminal case involving victims, community members and perpetrators for repair, reconciliation, and guaranteeing the continuity of the repair effort. Life in Indonesia does not recognize the existence of a Samenleven relationship because the law and religion do not justify it, but in fact there are still many perpetrators such as those in Bajo Village. Bajo customary law includes the Bajo Customary Institution which is an institution where its existence helps the village government in development and regulates matters relating to local customs as well as in solving problems regarding adultery, namely samenleven. The Bajo Customary Council uses customary law as a reference to resolve any problems that occur in Bajo Village, Tilamuta District, namely customary law by deliberation/mediation.

\section{ACKNOWLEDGMENTS}

We would like to thanks to our own leadership of institution in supporting this personal research. 


\section{REFERENCES}

Dermawan, R. N. (2015). Pribadi Muslimah dalam Novel Pingkan Sehangat Mentari Musim Semi Karya Muthmainnah: Perspektif Feminisme Islam. Caraka, 2(1), 1-20.

Efendi, E. (2018). Hukum Pidana Adat Gagasan Pluralisme dalam Hukum Pidana dan Penerapan Hukum Menurut Keyakinan Hukum. PT Refika Aditama.

Firhan, K. (2019). Eksistensi Hukum Pidana Adat Terhadap Pelaku Kohabitasi (Samenleven) Dalam Masyarakat Adat Bajo. Universitas Negeri Gorontalo.

Hamzah, A. (2014). Delik-Delik Tertentu Speciale Delicten di dalam KUHP. Sinar Grafika.

Hanim, L., \& Noorman, M. S. (2018). The Role of Indigenous Peoples and Customary Law in the Development of National Law the Paradigm of Pancasila. The 4th International and Call for Paper, 1(1).

Hikmah, M. (2013). Penundaan perkawinan bagi wanita hamil: Studi pandangan ulama dan pakar hukum terhadap kebijakan KUA Junrejo Kota Batu. Universitas Islam Negeri Maulana Malik Ibrahim.

Hoefnagels, G. P. (1969). The Other Side of Criminology, Holland. Kluwer Deventer.

Iskandar, S. (n.d.). Eksistensi Lembaga Adat sebagai Mitra Kerja Pemerintah Daerah.

Moeljatno. (2015). Asas-asas Hukum Pidana. PT Rineka Cipta.

Pide, A. S. M. (2017). Hukum Adat Dahulu, kini, dan akan datang. Prenada Media.

Wulansari, C. D., \& Gunarsa, A. (2016). Hukum adat Indonesia: suatu pengantar. Refika Aditama.

Zazili, A. (2016). Pengakuan Negara terhadap Hak-Hak Politik (Right to Vote) Masyarakat Adat dalam Pelaksanaan Pemilihan Umum (Studi Putusan Mahkamah Konstitusi No. 47-81/Phpu. A-Vii/2009). Jurnal Konstitusi, 9(1), $135-162$. 